\title{
МЕДИЧНА ЕКСПЕРТИЗА ЯК ОСНОВА СОЦІАЛЬНОГО ЗАХИСТУ ГРОМАДЯН, ЯКІ ПОСТРАЖДАЛИ ВНАСЛІДОК ЧОРНОБИЛЬСЬКОЇ КАТАСТРОФИ
}

\author{
ДУ «Національний науковий центр радіаційної медицини НАМН України», м. Київ, Україна
}

Мета: провести аналіз показників інвалідності постраждалих внаслідок аварії на чАЕС.

Матеріали і методи. У дослідженні використовували дані, надані ДЗ «Центр медичної статистики МОЗ України» та експертних комісій із встановлення зв'язку захворювань з наслідками аварії на ЧАЕС.

Результати. Загальна кількість постраждалих внаслідок аварії на ЧАЕС за останнє десятиріччя зменшилась на $26 \%$. Водночас зростають показники інвалідності серед постраждалого населення. Дві групи захворювань залишаються основними причинами інвалідності постраждалих внаслідок аварії на ЧАЕС - новоутворення та хвороби системи кровообігу. Завдяки діяльності експертних комісій більше 380 тис. постраждалих внаслідок Чорнобильської катастрофи змогли отримати матеріальну підтримку.

Висновки. Показники здоров'я постраждалого внаслідок аварії на ЧАЕС населення продовжують погіршуватися, що свідчить про необхідність впровадження в практику нових методів діагностики, лікування та реабілітації вказаної популяції, а також оновлення існуючої системи медико-соціальної експертизи.

КЛЮчОВІ СЛОВА: медична експертиза; Чорнобильська катастрофа; інвалідність; смертність.

Експертиза (від орранц. ехреrtise, від лат. ехpertus - досвідчений) - дослідження спеціалістом (експертом) визначених питань або проблеми, для вирішення яких потребує спеціальних знань і досвіду в галузі науки, техніки, медицини, мистецтва та ін. У медичній практиці виділяють такі види експертизи: експертиза тимчасової та стійкої втрати працездатності, військово-медична, судово-психіатрична, судово-медична.

Однією із основних проблем мінімізації наслідків аварії на Чорнобильській атомній електростанції (ЧАЕС) $€$ проблема медико-соціальної експертизи причинного зв'язку хвороб, інвалідності та причин смерті з дією іонізуючого випромінювання та інших шкідливих чинників в умовах аварії на ЧАЕС $[2,10]$. По суті це $€$ не тільки медичною, оскільки в основу проведення експертизи закладені не лише клініко-діагностичні критерії за визначеними групами хвороб, але й соціальною (терміни роботи із ліквідації наслідків аварії, доза опромінення, умови праці, наявність ознак непрацездатності, терміни розвитку хвороб після початку ліквідаційних робіт). За своїм призначенням експертиза спрямована на соціальний захист постраждалих від Чорнобильської катастрофи та їх медичну реабілітацію, що підтверджується положенням статті 12 Закону України «Про статус і соціальний захист громадян, які постраждали внаслідок Чорнобильської катастрофи» [8].

Проблема експертної оцінки зв'язку хвороб, що призвели до втрати здоров'я, працездатності та стали причиною смерті громадян внаслідок впливу аварії на ЧАЕС, з плином часу не тільки не зменшується, а навпаки - зростає [1]. Це пояснюється загальнобіологічними закономірностями реалізації ефектів дії іонізуючого опромінення на організм людини через визначені проміжки часу. Отже, зберігається необхідність організаційної фінансової, матеріально-технічної та кадрової підтримки забезпечення вирішення цього питання на державному рівні.

Мета роботи: провести аналіз показників інвалідності постраждалих внаслідок аварії на ЧАЕС, а також показників діяльності міжвідомчих експертних комісій (МЕК) щодо встановлення причинного зв'язку хвороб, інвалідності та смерті 3 дією іонізуючого випромінювання та інших шкідливих чинників внаслідок аварії на ЧАЕС.

Матеріали і методи. Дослідження проводили шляхом аналізу показників інвалідності та смертності учасників ліквідації наслідків аварії (УЛНА) на ЧАЕС, евакуйованих та проживаючих на території посиленого радіоекологічного контролю. Для вирішення цього завдання використовували дані, надані Державним закладом «Центр медичної статистики МОЗ України», експертними комісіями та спеціалізованими лікарсько-консультативними комісіями (спецЛКК) із встановлення зв'язку захворювань 3 впливом іонізуючого випромінювання та інших шкідливих чинників внаслідок аварії на ЧАЕС.

Результати дослідження та їх обговорення. На 01.01.2018 р. статус постраждалих внаслідок 
аварії на ЧАЕС мають 1868228 осіб, серед них 199006 УЛНА на ЧАЕС (10,65 \%), 1666387 постраждалих (89,2 \%), 2835 ядерщиків (0,15 \%). 3 плином часу після Чорнобильської катастрофри невпинно зростає частота інвалідності серед постраждалих; ця тенденція підтверджена демографічними і популяційними дослідженнями, проведеними в ІРГЕ ННЦРМ. Загальна кількість постраждалих громадян внаслідок аварії на ЧАEC у 2018 р., порівняно з 2007 р., зменшилась на 657988 осіб, або на 26,05 \%, і їх кількість продовжує невпинно зменшуватися. В той же час, відсоток постраждалих категорії 1 (особи 3 інвалідністю) не тільки не знижується, а й зростає: в 2010 р. вони становили 4,92 \%, в 2018 р. 5,73 \% від загальної кількості постраждалих.

Ця тенденція чітко простежується при аналізі кількості УЛНА. За останнє десятиріччя кількість УЛНА зменшилась на 77321 особу, або на 27,98 \% (рис. 1). У той же відсоток УЛНА, які втратили працездатність через хвороби, за якими встановлений причинний зв'язок із впливом наслідків аварії на ЧАЕС (тобто УЛНА категорії 1) у 2008 р. становила 23,65 \%, в 2018 р. - 29,18 \%. Це свідчить про зростання показників інвалідності серед постраждалого внаслідок аварії на ЧАЕС населення України.

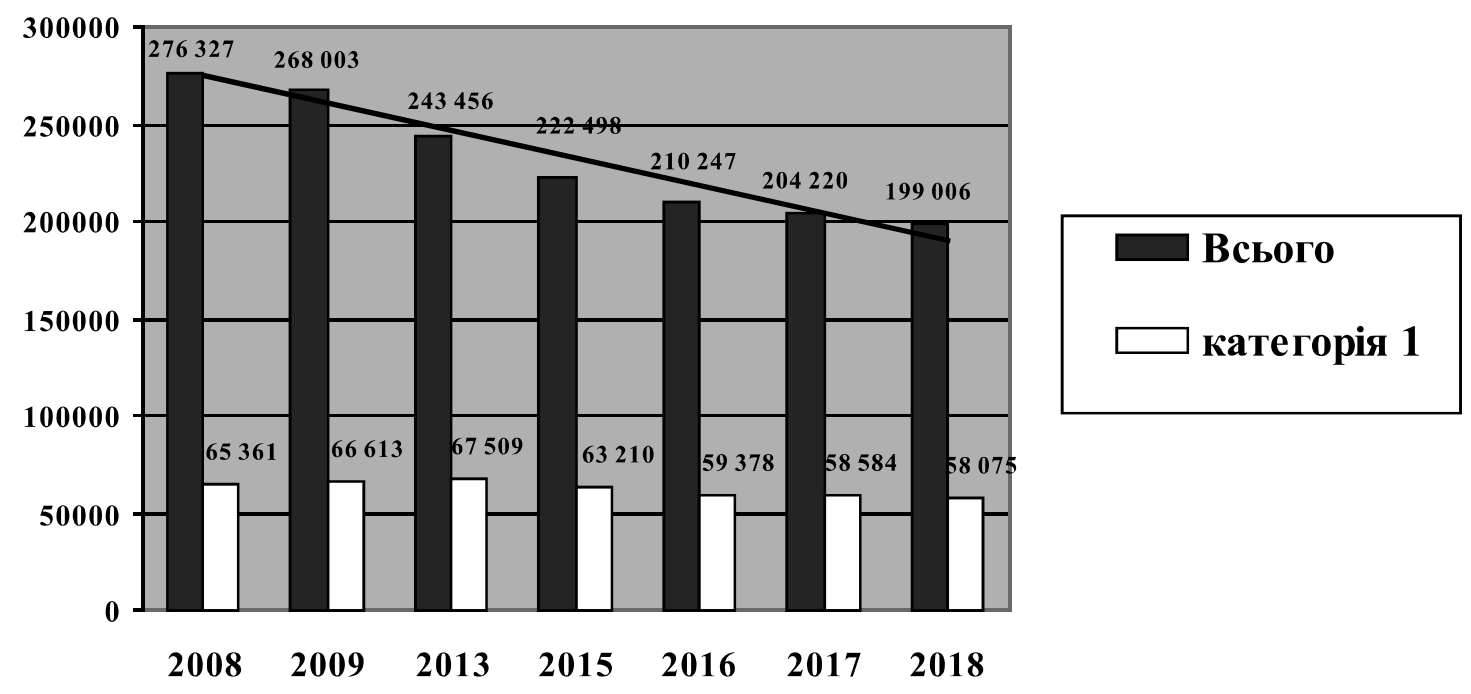

Рuc. 1. Динаміка кількості УлНА в цілому та категорії 1 впродовж 2008-2018 рр.

Дві групи захворювань залишаються основними причинами інвалідності постраждалих внаслідок аварії на ЧАЕС - новоутворення та хвороби системи кровообігу. До решти найчастіших причин інвалідності належать:

- від 2,1 до 2,6 \% від загальної кількості причин інвалідності - хвороби ендокринної системи, уроджені аномалії, захворювання органів дихання;

- менше 1 \% - психічні розлади, хвороби нервової системи, органів травлення, сечостатевої системи, крові та кістково-м'язової системи.

Станом на 01.01.2018 р. основна частина постраждалого населення проживає в Київській (609 395), Рівненській (334 667) та Житомирській (251 611) областях. У вказаних областях проживає 64 \% постраждалого населення. Значна кількість постраждалого населення (більше 100000 осіб на область) проживає у Волинській (131 915) та Черкаській (102 820) областях.

Основою соціального захисту постраждалих внаслідок аварії на ЧАЕС стало введення в дію Верховною Радою України 01 квітня 1991 р. Закону «Про статус і соціальний захист громадян, які постраждали внаслідок Чорнобильської катастрофи» [8], 12 стаття якого присвячена «Встановленню причинного зв'язку між захворюван- ням, пов'язаним з Чорнобильською катастрофою, частковою або повною втратою працездатності громадян, які постраждали внаслідок Чорнобильської катастрофи, і Чорнобильською катастрофрою». Суттєвий вплив на прийняття рішень з цього питання також мають статті 2, 14, 27 цього документа.

Упродовж 1997-2011 рр. діяв наказ МОЗ України від 17.05.1997 р. № 150 «Про затвердження нормативних актів щодо хвороб, при яких може бути встановлений причинний зв'язок з дією іонізуючого випромінювання та інших шкідливих чинників внаслідок аварії на Чорнобильській AEC» [5] та спільний наказ МОЗ і МНС України від 30 травня 1997 р. № 166/129 «Про удосконалення системи експертизи по встановленню причинного зв'язку хвороб, інвалідності і смерті з дією іонізуючого випромінювання та інших шкідливих чинників внаслідок аварії на Чорнобильській АEC» [9].

3 метою ведення єдиного реєстру осіб, яким надаються соціальні пільги внаслідок впливу іонізуючого випромінювання, відповідно до Рішення Урядової комісії від 13 серпня 1988 р. № 539 за погодженням із ВЦРПС та Держкомпраці СРСР був виданий наказ МО3 СРСР від 28 вересня 1988 р. № 731 «Про організацію Центральної Міжвідомчої 
експертної Ради по встановленню причинного зв'язку захворювань і інвалідності з роботами по ліквідації наслідків аварії на Чорнобильській АEC та їх професійного характеру» [6] на базі Всесоюзного наукового центру радіаційної медицини АМН СРСР. Цей наказ затвердив Положення і склад Центральної Міжвідомчої експертної комісії (ЦМЕК), яка є головним закладом щодо верифрікації діагнозів для встановлення причинного зв'язку в дорослого населення, постраждалого внаслідок аварії на ЧАЕС. Першим Головою Міжвідомчої Експертної Ради був призначений академік НАМНУ А. Ю. Романенко (1988-2007).

У цілому з 1988 до 2018 р. всіма нинішніми і колишніми експертними комісіями розглянуто більше 380000 справ постраждалих внаслідок аварії на ЧАЕС.

23 листопада 2011 р. п. 3 Постанови КМ України № 1210 «Про підвищення рівня соціального захисту громадян, які постраждали внаслідок Чорнобильської катастрофи» [7] та наступним спільним наказом МОЗ та МНС України від 10.10.2012 р. № 789/1248 «Про внесення змін до наказу МОЗ України та МНС України від 30 травня 1997 р. № 166/129» [4] ліквідовані обласні спеціалізовані лікарсько-консультативні комісії (ЛКК) та регіональні МЕК за винятком ЦМЕК, Донецької та Львівської регіональних комісій, внесені зміни до порядку процедури встановлення зв'язку захворювань.

ЦМЕК розглядає справи постраждалих внаслідок аварії на ЧАЕС, які проживають на території таких областей: Житомирська, Київська, Черкаська, Чернігівська та м. Києві, та розглядає звернення та апеляції 3 усіх регіонів України. Львівська РМЕК розглядає справи жителів Вінницької, Волинської, Закарпатської, Івано-Франківської, Львівської, Рівненської, Тернопільської, Хмельницької та Чернівецької областей; Донецька РМЕК - Автономної Республіки Крим та м. Севастополь, Дніпропетровської, Донецької, Запорізької, Кіровоградської, Луганської, Миколаївської, Одеської, Полтавської, Сумської, Харківської й Херсонської областей.

Внаслідок реструктуризації експертної системи з 2013 р. об'єм роботи ЦМЕК збільшився втричі й на сьогодні розглядає більш ніж 75 \% усіх справ, що подають на розгляд із приводу питань зв'язку захворювань, смерті та інвалідності з наслідками аварії на ЧАЕС (рис. 2).

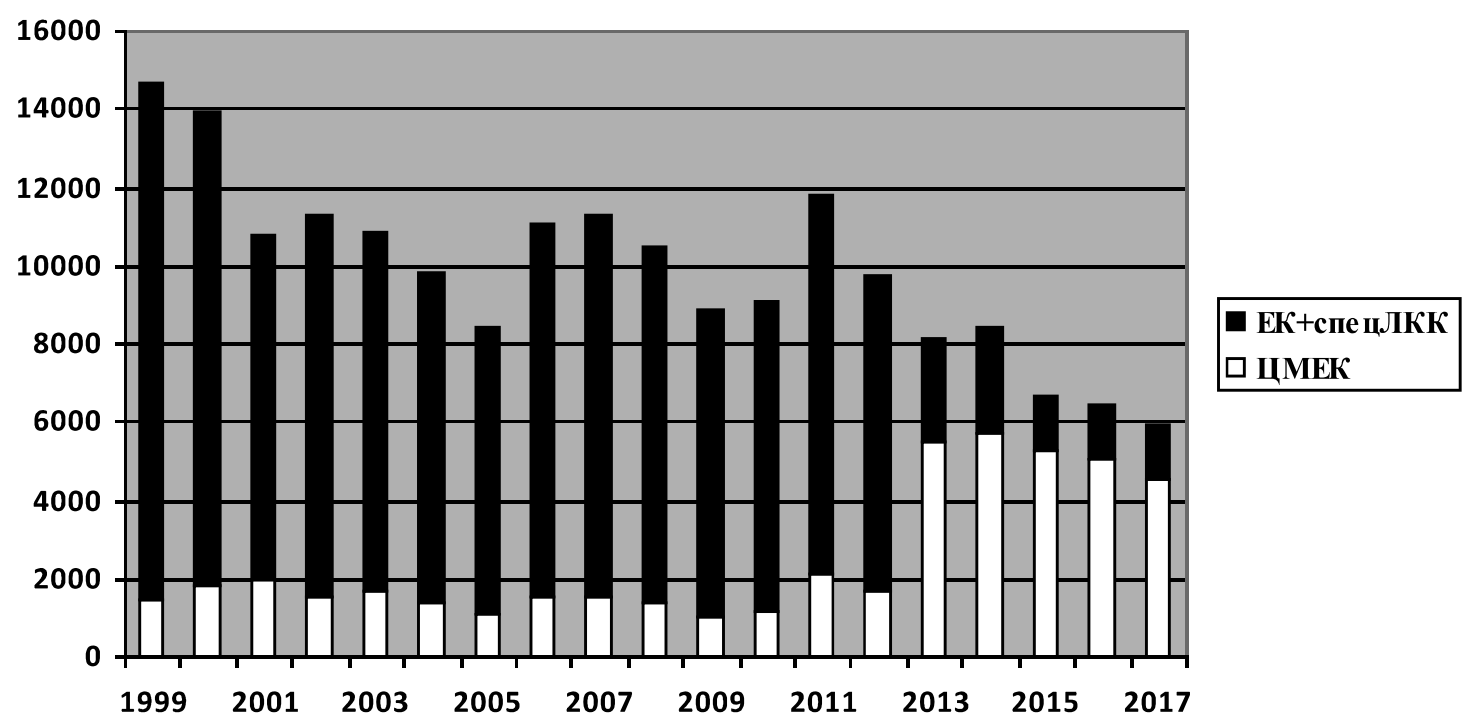

PUc. 2. Обсяги розгляду МЕК медичних справ постраждалих щодо встановлення зв'язку хвороб із впливом наслідків аварії на ЧАЕС.

Загалом впродовж 2013-2017 рр. відповідно до змін, затверджених вищезазначеними документами ЦМЕК, розглянуто 35656 медичних експертних справ постраждалих. У тому числі медичні справи:

- 18013 учасників ЛНА на ЧАЕС (50,5 \%);

- евакуйовані - 806 (2,2 \%);

- постраждалих 3 категорії - 5913 (16,5 \%);

- осіб, які проживають у зоні посиленого радіаційного контролю (4 категорія) - 9731 (27,3 \%);

- постраждалих, які до повноліття мали категорію «Д» 1193 (3,5 \%).
Згідно з наказом МО3 України від 14.06.2012 р. № 441 «Про внесення змін до наказу МОЗ України від 17 травня 1997 р. № 150» [3] було визначено перелік захворювань, за якими може бути встановлений зв'язок, та інструкцію щодо його застосування. Медико-соціальна оцінка радіобіологічних ефектів реалізації впливу наслідків аварії на Чорнобильській АЕС дозволяє розділити захворювання, що можуть бути пов'язані 3 дією цього впливу на групи:

1) хвороби, розвиток яких пов'язаний безпосередньо з дією іонізуючого випромінювання; 
2) хвороби, що виникли у віддалений період (новоутворення);

3) радіаційно-індуковані захворювання щитоподібної залози;

4) хвороби, розвиток яких пов'язаний 3 дією іонізуючого випромінювання та комплексу шкідливих чинників внаслідок аварії на ЧАЕС.

До 4 групи віднесли хвороби, розвиток яких пов'язаний $з$ дією іонізуючого випромінювання та комплексом шкідливих чинників внаслідок аварії на ЧАЕС. В цю групу ввійшли найрозповсюдженіші неонкологічні захворювання, у тому числі хвороби системи кровообігу. Стосовно цієї групи захворювань, яка за питомою вагою займає близько 40 \% від усіх причин встановлення зв'язку з впливом наслідків аварії на ЧАЕС, то згідно $з$ наказом МО3 України від 14.06.2012 р. № 441 «Про внесення змін до наказу МОЗ України від 17 травня 1997 р. № 150» [3] питання про причинний зв'язок вирішується ЦМЕК та регіональними МЕК для всіх категорій постраждалих за наявності витягу 3 акту огляду медико-соціальної експертної комісії щодо стійкої втрати працездатності, тобто лише в осіб, яким встановлено групу інвалідності. Ця вимога була зумовлена впливом наслідків аварії, якщо він дійсно мав місце як нестохастичний ефект, мав реалізуватися до рівня декомпенсації за 25 років після аварії, тоді як стохастичні ефректи (онкологічні та радіаційно зумовлені захворювання) не мають терміну давності.

Існуюча система медико-соціальної експертизи встановлення причинного зв'язку захворювань, інвалідності та причин смерті 3 впливом наслідків аварії на ЧАЕС потребує суттєвого удосконалення, яке має полягати в перегляді та оновленні діючих нормативно-регуляторних документів МО3 та МНС України. Існує необхідність удосконалення нормативно-правової бази експертизи, а саме:

- внесення змін у статті 12, 14, 27 Закону України «Про статус і соціальний захист громадян, які постраждали внаслідок Чорнобильської катастрофи», а також статті 4, 11, 17, 20, 22, 30, 55.

- внесення змін до Закону України «Про статус і соціальний захист громадян, які постраждали внаслідок Чорнобильської катастрофи»» (статті 4, 7, п. 7; п. 4 ч. 1 ст. 11; п. 4. ч. 1 ст. 14; ч. 1 ст. 17) щодо визначення статусу постраждалих дітей, які після досягнення повноліття втратили цей статус і захворіли на онкологічні (насамперед щитоподібної залози) та онкогематологічні захворювання, а також стосовно гарантування медичного забезпечення нащадкам постраждалих другого, третього і наступних поколінь. Наполягати на уточненні до цього закону, за яким відміна статусу території, що мала певну категорію радіаційного забруднення, не передбачає відміну або втрату статусу постраждалих для мешканців цієї території, які прожили під дією радіаційного чинника відповідну кількість років.

\section{Висновки}

Загальна кількість постраждалих внаслідок аварії на ЧАЕС жителів України за останнє десятиріччя зменшилась на 26,05 \% і їх кількість продовжує невпинно зменшуватися. Водночас зростають показники інвалідності серед постраждалого населення. Дві групи захворювань залишаються основними причинами інвалідності постраждалих внаслідок аварії на ЧАЕС - новоутворення та хвороби системи кровообігу. За роки існування системи експертизи із встановлення зв'язку захворюваності, інвалідності та смертності постраждалих внаслідок аварії на ЧАЕС всіма нинішніми і колишніми експертними комісіями розглянуто більше 380 тис. справ, що дозволило значній кількості постраждалих внаслідок Чорнобильської катастрофри отримати відповідну матеріальну підтримку.

Перспективи подальших досліджень полягають у розробці, апробації та впровадженні в практику на основі належної медичної практики нових методів діагностики, лікування та реабілітації постраждалих внаслідок Чорнобильської катастрофи. Важливою $є$ медична експертна оцінка зв'язку хвороб, стійкої втрати працездатності та причин смерті з дією іонізуючого випромінювання та інших шкідливих чинників внаслідок аварії на Чорнобильській AEC, а також оновлення існуючої законодавчої та нормативно-регуляторної бази та приведення її у відповідність до цивільних стандартів Європейського Союзу.

\section{Список літератури}

1. Бебешко В. Г. Радіо-біофізичні та медико-гігієнічні наслідки Чорнобильської катастросри: шляхи пізнання та подолання : практ. посібн. сімейного лікаря / [В. Г. Бебешко, Б. С. Прістер, М. І. Омельянець]. - Ужгород : «Патент». 2017. - С. 456-459.

2. Післяаварійні зміни стану здоров'я учасників ліквідації наслідків аварії на ЧАЕС 1986-1987 рр. (період спостереження 1988-2012 рр.) [Електронний ресурс] / В. О. Бузунов, Ю. С. Войчулене, Т. Є. Домашевська [та ін.] // Проблеми радіаційної медицини та радіобіології. - 2015. - Вип. 20. - С. 157-173. - Режим доступу : http://www. radiationproblems.org.ua/20_2015_ru_s157.html.

3. Про внесення змін до наказу МОЗ України від 17 травня 1997 р. № 150 : наказ МОЗ України від 14.06.2012 р. № 441 [Електронний ресурс]. - Режим доступу : http://zakon2.rada.gov.ua/laws/show/z1458-12

4. Про внесення змін до наказу МОЗ України та МНС України від 30 травня 1997 р. № 166/129 : наказ МОЗ і МНС України № 789/1248 [Електронний ресурс]. - Режим доступу : http://zakon3.rada.gov.ua/laws/show/z2108-12 
5. Про затвердження нормативних актів щодо хвороб, при яких може бути встановлений причинний зв'язок з дією іонізуючого випромінювання та інших шкідливих чинників у дорослого населення, яке постраждало внаслідок аварії на Чорнобильській АЕС : наказ МОЗ України від 17.05.1997 р. № 150 [Електронний ресурс]. - Режим доступу : httр:// zakon3.rada.gov.ua/laws/show/z0448-97

6. Про організацію Центральної Міжвідомчої експертної Ради по встановленню причинного зв'язку захворювань і інвалідності з роботами по ліквідації наслідків аварії на Чорнобильській АЕС та їх професійного характеру : наказ МОЗ СРСР від 28.09.1988 р. № 731.

7. Про підвищення рівня соціального захисту громадян, які постраждали внаслідок Чорнобильської катастрофи : Постанова КМ України від 23.11.2011 р. № 1210 [Електронний ресурс]. - Режим доступу : http://zakon3.rada.gov.ua/ laws/show/1210-2011-\%D0\%BF

8. Про статус і соціальний захист громадян, які постраждали внаслідок Чорнобильської катастрофи : Закон України від 28 лютого 1991 р. № 796-XII в редакції Закону від 06 червня 1996 р. № 230/96-ВР [Електронний ресурс]. - Режим доступу : http://zakon0.rada.gov.ua/laws/show/796-12

9. Про удосконалення системи експертизи по встановленню причинного зв'язку хвороб, інвалідності і смерті з дією іонізуючого випромінювання та інших шкідливих чинників внаслідок аварії на Чорнобильській АЕС : спільний наказ МОЗ і МНС України від 30.05.1997 р. № 166/129 [Електронний ресурс]. - Режим доступу : http://zakon0.rada.gov.ua/ laws/show/z0491-97

10. Зороків Чорнобильської катастрофи: радіологічнітамедичнінаслідки:НаціональнадоповідьУкраїни[Електронний ресурс]. - К., 2016. - 177 с. - Режим доступу : https://drive.google.com/file/d/OB1bUIW1YACgZNWIzYXRmejZHc2M/ view

\section{References}

1. Bebeshko, V.H., Prister B.S., \& Omelianets M.I. (2017). Radio-biofizychni ta medyko-hihiienichni naslidky Chornobylskoi katastrofy: shliakhy piznannia ta podolannia [Radiobiophysical and medical and hygienic consequences of the Chernobyl catastrophe: ways of knowing and overcoming: the practice. manual family doctor]. Uzhhorod: "Patent" [in Ukrainian].

2. Buzunov, V.O., Voichulene, Yu.S., Domashevska, T.Ye., Khabarova, T.P., \& Kortushin, H.I. (2015). Pisliaavariini zminy stanu zdorovia uchasnykiv likvidatsii naslidkiv avarii na ChAES 1986-1987 (period sposterezhennia 1988-2012) [After accidental changes in the health status of participants in the liquidation of the consequences of the Chernobyl accident in 1986-1987 (observation period 1988-2012)]. Problemy radiatsiinoi medytsyny ta radiobiolohii - Problems of Radiation Medicine and Radiobiology, (20), 157-173. - Retrieved from: http://www.radiationproblems.org.ua/20_2015_ru_s157.html [in Ukrainian].

3. Pro vnesennia zmin do nakazu MOZ Ukrainy vid 17 travnia 1997 roku № 150. Nakaz MOZ Ukrainy № 441 vid 14.06 .2012 r. [On amendments to the Order of the Ministry of Health of Ukraine dated May 17, 1997 № 150: Order of the Ministry of Health of Ukraine dated 14.06.2012, No. 441]. - Retrieved from: http://zakon2.rada.gov.ua/laws/show/z1458-12 [in Ukrainian].

4. Pro vnesennia zmin do nakazu MOZ Ukrainy ta MNS Ukrainy vid 30 travnia 1997 roku № 166/129. Nakaz MOZ i MNS Ukrainy № 789/1248 [On Amendments to the Order of the Ministry of Health of Ukraine and the Ministry for Emergencies of Ukraine of May 30, 1997 No. 166/129: Order of the Ministry of Health and Emergencies of Ukraine No. 789/1248]. Retrieved from: http://zakon3.rada.gov.ua/laws/show/z2108-12 [in Ukrainian].

5. Pro zatverdzhennia normatyvnykh aktiv shchodo khvorob, pry yakykh mozhe buty vstanovlenyi prychynnyi zviazok z diieiu ionizuiuchoho vyprominiuvannia ta inshykh shkidlyvykh chynnykiv u dorosloho naselennia, yake postrazhdalo vnaslidok avarii na Chornobylskii AES. Nakaz MOZ Ukrainy № 150 vid 17.05.1997 r. [On approval of normative acts on diseases in which a causal link with the action of ionizing radiation and other harmful factors in an adult population affected by the accident at the Chernobyl Nuclear Power Plant could be established: the Order of the Ministry of Health of Ukraine dated May 17, 1997 No. 150]. - Retrieved from: http://zakon3.rada.gov.ua/laws/show/z0448-97. [in Ukrainian].

6. Pro orhanizatsiiu Tsentralnoi Mizhvidomchoi ekspertnoi Rady po vstanovlenniu prychynnoho zviazku zakhvoriuvan i invalidnosti z robotamy po likvidatsii naslidkiv avarii na Chornobylskii AES ta yikh profesiinoho kharakteru. Nakaz MOZ SRSR №731 vid 28.09.1988 r. [On the Organization of Central Interagency Advisory Council to establish causation of disease and disability from work in the aftermath of the Chernobyl accident and their professional character order of the Ministry of Health of 28.09.1988 p. No. 73]. [in Ukrainian].

7. Pro pidvyshchennia rivnia sotsialnoho zakhystu hromadian, yaki postrazhdaly vnaslidok Chornobylskoi katastrofy. Postanovy KM Ukrainy vid 23.11.2011 r. № 1210 [On raising the level of social protection of citizens who suffered as a result of the Chernobyl disaster. "Resolution of the Cabinet of Ministers of Ukraine dated November 23, 2011 No. 1210]. Retrieved from: http://zakon3.rada.gov.ua/laws/show/1210-2011-\%D0\%BF [in Ukrainian].

8. Pro status i sotsialnyi zakhyst hromadian, yaki postrazhdaly vnaslidok Chornobylskoi katastrofy. Zakon Ukrainy vid 28 liutoho 1991 r. № 796-Khll v redaktsii Zakonu vid 6 chervnia 1996 r. № 230/96-VR [About the status and social protection of citizens who suffered as a result of the Chernobyl disaster: Law of Ukraine dated February 28, 1991 No. 796-XII as amended by the Law No. 230/96-VR of June 6, 1996]. - Retrieved from: http://zakon0.rada.gov.ua/laws/show/796-12 [in Ukrainian].

9. Pro udoskonalennia systemy ekspertyzy po vstanovlenniu prychynnoho zviazku khvorob, invalidnosti i smerti z diieiu ionizuiuchoho vyprominiuvannia ta inshykh shkidlyvykh chynnykiv vnaslidok avarii na Chornobylskii AES. Spilnyi Nakaz MOZ i MNS Ukrainy № 166/129 vid 30.05.1997 r. [On improvement of the system of examination for determining the causal relationship of illness, disability and death with the effect of ionizing radiation and other harmful factors as a result of the 
Chernobyl accident: the joint order of the Ministry of Health and Emergencies of Ukraine dated May 30, 1997 No. 166/129]. Retrieved from: URL: http://zakon0.rada.gov.ua/laws/show/z0491-97. [in Ukrainian].

10. 30 rokiv Chornobylskoi katastrofy: radiolohichni ta medychni naslidky. Natsionalna dopovid Ukrainy [30 years of the Chernobyl disaster: radiological and medical consequences. National report of Ukraine]. Kyiv. - Retrieved from: https:// drive.google.com/file/d/0B1bUIW1YACgZNWIzYXRmejZHc2M/view [in Ukrainian].

\section{МЕДИЦИНСКАЯ ЭКСПЕРТИЗА КАК ОСНОВА СОЦИАЛЬНОЙ ЗАЩИТЫ ГРАЖДАН, ПОСТРАДАВ- ШИХ В РЕЗУЛЬТАТЕ ЧЕРНОБЫЛЬСКОЙ КАТАСТРОФЫ}

О.Н. Татаренко, Е.А. Колосинская, В.А. Сушко, Г.А. Незговорова

ГУ «Национальный научный центр радиационной медицины НАМН Украины», г. Киев, Украина

Цель: провести анализ показателей инвалидности пострадавших вследствие аварии на ЧАЭС.

Материалы и методы. В исследовании использовали данные, предоставленные ГУ «Центр медицинской статистики МЗ Украины» и экспертными комиссиями по установлению связи заболеваний с последствиями аварии на ЧАЭС.

Результаты. Общее количество пострадавших вследствие аварии на ЧАЭС за последнее десятилетие уменьшилось на 26 \%. Отмечен рост показателей инвалидности среди пострадавшего населения. Две группы заболеваний остаются основными причинами инвалидности пострадавших вследствие аварии на ЧАЭС - новообразования и болезни системы кровообращения. Благодаря деятельности экспертных комиссий больше 380 тыс. пострадавших в результате Чернобыльской катастрофы смогли получить материальную поддержку.

Выводы. Показатели здоровья пострадавшего вследствие аварии на ЧАЭС населения продолжают ухудшаться, что свидетельствует о необходимости внедрения в практику новых методов диагностики, лечения и реабилитации указанной популяции, а также обновления существующей системы медикосоциальной экспертизы.

КЛЮЧЕВЫЕ СЛОВА: медицинская экспертиза; Чернобыльская катастрофа; инвалидность; смертность.

\section{MEDICAL EXPERTISE AS THE BASIS OF SOCIAL PROTECTION OF CHORNOBYL CATASTROPHE VICTIMS}

O.M. Tatarenko, O.O. Kolosinska, V.O. Sushko, G.A. Nezgovova

National Scientific Center of Radiation Medicine of the NAMS of Ukraine, Kyiv, Ukraine

Purpose: to analyze the indicators of disability of the Chornobyl victims.

Materials and Methods. Data provided by the State Medical Service Center "Center of Medical Statistics of the Ministry of Health of Ukraine" and expert commissions to establish a relationship of diseases with the consequences of the Chernobyl accident were analyzed.

Results. The total number of Chernobyl victims in the last decade has decreased by $26 \%$. It is shown increasing of disability among the affected population. Malignancy and circulatory system diseases are the two groups of diseases remain the main causes of the disability. More than 380000 Chernobyl victims have been able to obtain material support due to the work of expert commissions.

Conclusions. Health indicators of the Chernobyl victims continue to deteriorate, indicating the necessity to introduce new methods of diagnosis, treatment and rehabilitation of the specified population, as well as updating the existing system of expertise.

KEY WORDS: expertise; Chornobyl catastrophe; disability; mortality.

Рукопис надійшов до редакції 01.06.2018 p.

\section{Відомості про авторів:}

Татаренко Ольга Миколаївна - науковий співробітник, відділу медичної експертизи та лікування наслідків впливу радіаційного опромінення; тел.: +38(063) 238-30-24.

Колосинська Олена Олександрівна - кандидат медичних наук, провідний науковий співробітник відділу медичної експертизи та лікування наслідків впливу радіаційного опромінення; тел.: +38(067) 788-52-25.

Сушко Віктор Олександрович - доктор медичних наук, профресор, керівник відділу медичної експертизи та лікування наслідків впливу радіаційного опромінення.

Незговорова Галина Андріївна - кандидат медичних наук, науковий співробітник відділу медичної експертизи та лікування наслідків впливу радіаційного опромінення; тел.: +38(050) 355-37-61. 